\title{
Enhancing sensitivity of chemoresistant ovarian cancer cells to TRAIL and FAS mediated apoptosis by radiation
}

\section{Kemorezistant over kanser hücrelerinin TRAIL ve FAS aracilı apoptoz duyarlılıklarının radyasyon ile arttırılması}

\author{
Ercan CACAN ${ }^{1}$
}

\section{ABSTRACT}

Objective: Death receptors initiate apoptotic signals following interaction with their cognate ligands. However, expressions of death receptors are often downregulated during ovarian cancer progression and it has been recently asserted that suppression of death receptors is associated with resistance to chemotherapeutic drugs in ovarian cancer cells. Radiotherapy is a common treatment modality for several cancer types and it has been reported that low-dose ionizing radiation modulates tumor microenvironment. The purpose of the present study is to determine if sublethal ionizing radiation will modulate the expression of common death receptors in chemoresistant ovarian cancer cells and to investigate if reversed expression of death receptors will enhance TRAIL or FAS ligand (FASL) mediated apoptosis.

Methods: Flow cytometry analyses were performed to determine the effects of chemotherapeutic drug, cisplatin, on chemosensitive and chemoresistant ovarian cancer cells viability, cellular expressions of death receptors and TRAIL or FAS mediated apoptosis, following sub-lethal irradiation in drug resistant ovarian cancer cells.

Results: The majority of chemoresistant A2780$A D$ cells remain viable following a high dose of

\section{ÖZET}

Amaç: Ölüm reseptörleri, ligandları ile etkileșime girerek apoptotik sinyallerini bașlatmaktadır. Ancak over kanserinin gelișimi sürecinde ölüm reseptörlerinin ekspresyonu sıklıkla baskılanmaktadır ve son yıllarda over kanse hücrelerindeki ölüm reseptörlerini baskılanmasının kemoterapötik ilaçlara karșı olușturulan direnç mekanizmaları ile ilișkili olduğu öne sürülmüștür. Radyoterapi çeșitli kanser tiplerinde yaygın bir tedavi yöntemidir ve düșük dozda iyonize radyasyonun tümörün mikro çevresini etkilediği rapor edilmiștir. Bu çalıșmanın amacı ölümcül olmayan iyonize radyasyonun kemorezistan over kanseri hücrelerinde ölüm reseptörlerinin ekspresyonunu değiștirip değiștirmeyeceğinin belirlenmesi ve expresyonu arttırılmış ölüm reseptörlerinin TRAIL ya da FAS ligand (FASL) aracıl apoptozu arttırıp arttırmayacağının araștırıımasıdır.

Yöntem: Illaca dirençli over kanseri hücrelerinde düşük dozlardaki radyasyona maruz bırakıldıktan sonra, kemoterapötik ilacın (sisplatin) kemosensitif ve kemorezistan over kanseri hücrelerinin canlılığını, ölüm reseptörlerinin hücresel expresyonunu ve FAS veya TRAIL aracılığıyla gerçekleșen apoptoz üzerine etkilerini saptamak amavıyla flow sitometri analizleri kullanılmıștır.

Bulgular: İlaçlara duyarılık gösteren A2780 hücreleri düşük dozdaki ilaca maruz kalmanın ardından ölmeye

'Department of Molecular Biology and Genetics, Gaziosmanpasa University, Tokat

DOI ID : 10.5505/TurkHijyen.2017.12499

Cacan E. Enhancing sensitivity of chemoresistant ovarian cancer cells to TRAIL and FAS mediated apoptosis by radiation.

Turk Hij Den Biyol Derg, 2017; 74(3): 185-192 
cisplatin treatment, while the drug sensitive A2780 cells started to die following low dose drug exposure. The results have demonstrated that 2 Gy or $5 \mathrm{~Gy}$ ionizing radiation enhances expression of death receptors, FAS and DR4, in multi drug resistant A2780-AD ovarian cancer cells. The data further have confirmed that sub-lethal ionizing radiation increases FAS/TRAIL-mediated apoptosis of the chemoresistant ovarian tumor cells.

Conclusion: This study has suggested that sublethal radiation treatment may simultaneously increase immunogenicity of tumor cells and the induction of antitumor immunity to chemoresistant ovarian cancer cells.

Key Words: Ovarian cancer, chemoresistance, FAS, TRAIL, radiation

\section{INTRODUCTION}

Each year, over 240.000 women are diagnosed with ovarian carcinoma and less than half of these women live five years beyond their diagnosis, making epithelial ovarian cancer the most deadly gynecological cancer (1). Major factors in the extremely low survival rate are late diagnosis and the high incidence of acquired chemoresistance (2). The first line therapeutic drug cisplatin is initially very effective, but more than $80 \%$ of patients whose tumors initially respond to cisplatin relapse within two years with drug-resistant, terminal disease (3, 4). To address this clinical problem, it is absolutely necessary to develop new strategies for the treatment of ovarian cancer to overcome resistance to chemotherapeutic drugs. Cancer immunotherapy approaches are now increasingly being investigated for the treatment of malignancy, thus different immunotherapy strategies for ovarian cancer might overcome chemoresistance.

FAS (CD95/Apo-1), DR5 (TRAIL-R2) and DR4 başladıkları halde yüksek dozdaki sisplatin muamelesinin ardından kemorezistan A2780-AD hücrelerinin büyük bir kısmı canlılığını sürdürmüștür. Sonuçlar 2 Gy yada 5 Gy iyonize radyasyonun çoklu ilaçlara dirençli A2780-AD over kanseri hücrelerinde ölüm reseptörlerinin, FAS ve DR4, expresyonunu arttırdığını göstermiștir. Veriler ölümcül olmayan iyonize radyasyon, kemorezistan over kanseri hücrelerinin FAS ve TRAIL aracılı apoptozu arttırdığını doğrulamıștır.

Sonuç: Bu çalıșma düşük doz radyasyon tedavisinin doğal olarak tümör hücrelerinin immünojenitisini arttırabileceğini ve anti-tümör immüniteyi indükleyebileceğini akla getirmiștir.

Anahtar Kelimeler: Over kanseri, kemoterapi, FAS, TRAIL, radyasyon

(TRAIL-R1) are death receptors that are commonly utilized by cytotoxic T lymphocytes (CTLs) to induce apoptotic signals in tumor cells. These death receptors contain death domain which allows the receptors to trigger apoptotic signals following interaction with their cognate ligands (5). FASL induces apoptosis through binding its cognate receptor FAS, and TRAIL induces apoptotic signal in tumor cell through binding its receptors DR5 and DR4. TRAIL or FASL ligation to its receptor results in trimerization of the receptor and subsequently leading to activation of caspase-3 (6). It has been reported that TRAIL exposure makes cancer cells more sensitive to TRAlL-induced apoptosis compare to normal cells (7, 8). However, tumor cells often avoid FASL and TRAIL-mediated apoptosis by suppressing expression of death receptors, which weakens the interaction between these death receptors and their cognate ligands during cancer progression (9-11). It has been recently shown that FAS suppression is associated 
with resistance to chemotherapeutic drugs in ovarian cancer cells (12) and upregulation of FAS reverses the development of resistance to cisplatin in ovarian cancer cells (13). Thus, knowledge about death receptor-mediated signaling pathways may offer new therapeutic approaches and could enhance sensitivity of tumor cells to CTLs-mediated killing.

The goal of the present study is to investigate if the expression of death receptors will be modulated by sub-lethal ionizing radiation in chemoresistant ovarian cancer cells and to determine whether reversed expression of death receptors will enhance TRAIL or FAS mediated apoptosis.

\section{MATERIAL and METHOD}

\section{Reagents and cell lines}

The parental chemosensitive (A2780) cells and their derivative drug-resistant (A2780-AD) ovarian cancer cells were provided by Dr. Shelly B. Hooks, University of Georgia. These cells were cultured in RPMI1640 medium (Mediatech Inc; Manassas, VA, USA) included with $5 \mathrm{mM}$ penicillin-streptomycin, $10 \% \mathrm{FBS}$ and $5 \mathrm{mM} \mathrm{L}$-glutamine at $37^{\circ} \mathrm{C}$ with $5 \% \mathrm{CO}$. The resistant cells were further cultured in $3 \mu \mathrm{M}$ of cisplatin (Sigma-Aldrich; St. Louis, MO, USA).

\section{Cisplatin-deriven cell death assay}

The 7-Aminoactinomycin $D$ (7-AAD) (BD Pharmingen; Franklin Lakes, New Jersey, USA) was used to measure percentage of dead cells. Tumor cells were cultured in variety of cisplatin concentrations. Following $24 \mathrm{~h}$ incubation, the tumor cells were trypsinized, harvested and washed with cold PBS. 1 $x 10^{6}$ cells $/ \mathrm{mL}$ were then resuspended in a binding buffer. The samples were stained with $5 \mu \mathrm{L}$ of 7-AAD and incubated for $20 \mathrm{~min}$ at room temperature. Following staining, the samples were acquired on flow cytometry. FlowJo software was used to analyze the resulting data. Dead cells were positive for 7-AAD and viable cells were negative for 7-AAD labeling.

\section{Irradiation}

Tumor cells were kept on ice and irradiated at a dose rate of $2 \mathrm{~Gy} / \mathrm{min}$ by setting irradiator current and voltage at $25 \mathrm{~mA}$ and $160 \mathrm{kV}$. The cells were maintained in recommended media during irradiation. After irradiation, the cells media was substituted with the recommended fresh media.

Flow cytometry analysis and cell surface staining

Chemoresistant ovarian cancer cells were control-irradiated ( $0 \mathrm{~Gy}$ ), irradiated with 2 Gy or $5 \mathrm{~Gy}$ and then cultured with fresh media for $48 \mathrm{~h}$. The cells were harvested and stained with the PEDR4, APC-DR5, PE-FAS, and the suitable isotype matched antibodies for control (BioLegend; San Diego, CA, USA). For staining, the tumor cells were mixed with an indicated antibody and incubated in a cell-staining buffer on ice for 45 min. The stained cells were rinsed with PBS and then acquired and quantified by flow cytometry. Based on scatter profile, dead cells were omitted from the analyzed cells. Isotype matched control staining was kept smaller than $5 \%$.

\section{FAS and TRAIL mediated apoptosis assay}

A2780-AD cells were control-irradiated ( $0 \mathrm{~Gy}$ ), irradiated with $2 \mathrm{~Gy}$ or $5 \mathrm{~Gy}$ and then re-cultured with fresh media for $48 \mathrm{~h}$. The chemoresistant tumor cells were harvested, counted and incubated for $3 \mathrm{~h}$ with recombinant TRAIL protein (Millipore; Billerica, MA, USA), agonistic anti-FAS antibody, clone CH11 (MBL; Watertown, MA, USA) or isotype control antibody, IgM (BD Biosciences; San Diego, CA, USA). Cells were subsequently stained with a PE-labeled monoclonal antibody for apoptotic marker intracellular active caspase-3 (BD Biosciences; San Diego, CA, USA). A flow cytometer was used to analyze stained cells. The level of activated caspase- 3 was quantified by flow cytometry. 


\section{Statistical analysis}

Student paired t test was used to evaluate the obtained results. The normality of data was checked by Shapiro-Wilk test. Values show the standard error of the mean (SEM) of three independent experiments. The $p$ values $<0.05,<0.005,<0.0005$ are indicated by asterisks $\left({ }^{*}\right),\left({ }^{* *}\right),\left({ }^{* * *}\right)$, respectively.

\section{RESULTS}

Effects of cisplatin on chemosensitive and chemoresistant ovarian cancer cells viability

Two well-characterized ovarian cancer cell lines were used to investigate the effects of cisplatin on tumor cell death. The ovarian tumor cells were treated with different concentrations of cisplatin and cultured for $24 \mathrm{~h}$. Cell death was detected based on 7-AAD staining. The population of live and dead cells was distinguished by flow cytometry analysis. Our data showed that more than $50 \%$ of chemosensitive, A2780, cells were killed following $50 \mu \mathrm{M}$ of cisplatin treatment. In contrast, only $8 \%$ of A2780-AD cells died at the same cisplatin concentration. Majority of A2780 cells were killed following $100 \mu \mathrm{M}$ cisplatin treatment, however greater than $80 \%$ of $A 2780-A D$ cells remained viable after $100 \mu \mathrm{M}$ cisplatin treatment (Figure 1). The data revealed that most of A2780-AD cells remain viable following a high dose of cisplatin treatment, however the drug sensitive A2780 cells start to die following low dose drug exposure.

Sub-lethal ionizing radiation upregulates expression of some death receptors in resistant ovarian cancer cells

Suppression of some members of death receptors was observed in variety of cancer cell lines $(14,15)$ and we have recently observed that some member of TNFRSF (DR4 and FAS) are suppressed in resistant ovarian cancer cells (12). To determine whether suppressed FAS and DR4 surface expressions can be reversed by sub-lethal radiation, cell surface expressions of FAS and DR4 were investigated following 0,2 or $5 \mathrm{~Gy}$ irradiation of chemoresistant cells. Radiation treatment did not cause any alterations in the surface expression of DR5 on the resistant cells because DR5 was already highly expressed on A2780-AD cells (Figure 2a). In contrast to DR5 expression, both 2 Gy and 5 Gy treatments significantly increased FAS and DR4 surface protein expressions in chemoresistant ovarian cancer cells (Figure 2b-c). Overall, our data indicate that sublethal ionizing radiation had significant effect on expression of FAS and DR4 in drug resistant ovarian cancer cells.

A

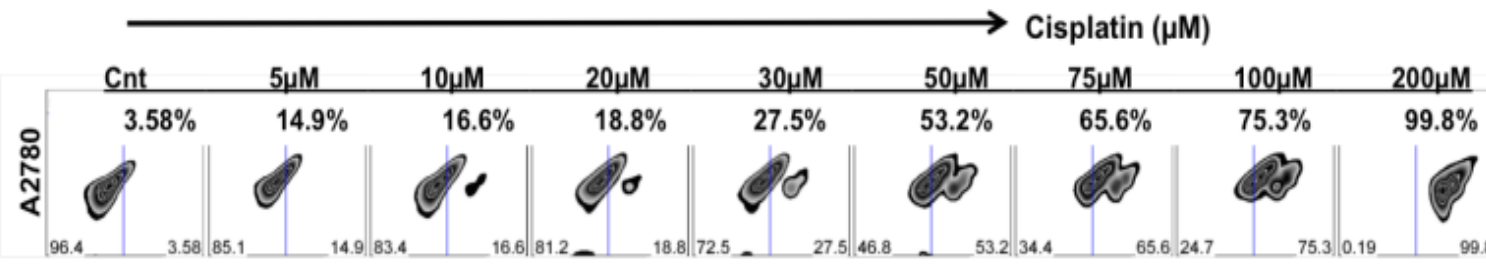

B

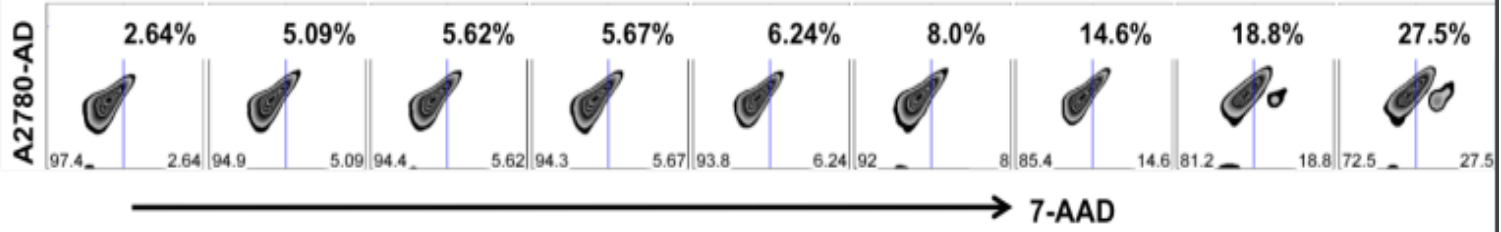

Figure 1. The percentage of dead tumor cells in (a) chemosensitive and (b) chemoresistant ovarian cancer cells after cisplatin exposure.

Cells were cultured in presence of variety concentration of cisplatin for $24 \mathrm{~h}$. Adherent cells were subsequently harvested and cell death was analyzed by 7-AAD staining and flow cytometric analysis. Experiment was repeated 3 times with similar results. 
A

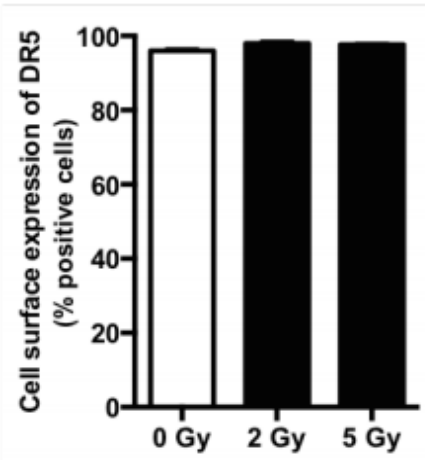

B

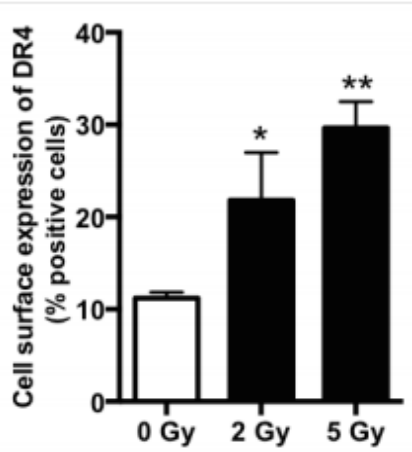

C

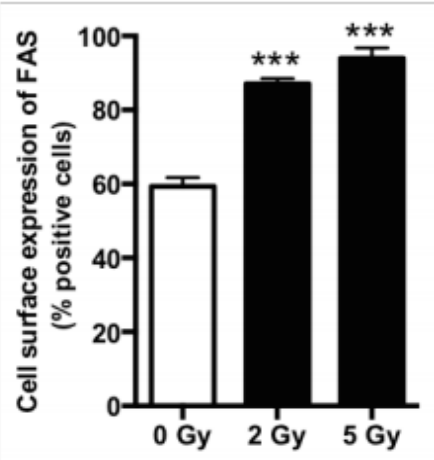

Figure 2. Cells surface expression of sub-lethal ionizing radiation.

(a) DR5, (b) DR4 and (c) FAS in chemoresistant A2780-AD cells following Cells were harvested and stained with PE-labeled antibody to human DR4, FAS or APC-labeled DR5. Cell surface protein expression was evaluated by flow cytometry.

Radiation treatment enhanced sensitivity of resistant cells to killing through TRAIL and FASL receptors

Our data clearly demonstrate that sub-lethal ionizing radiation enhances expression of FAS and DR4 on chemoresistant ovarian cancer cells. To determine whether increased expression of FAS and DR4 on chemoresistant ovarian cancer cells by sublethal radiation is functional, $A 2780-A D$ cells were control-irradiated $(0 \mathrm{~Gy})$, irradiated with 2 Gy or 5 Gy. Following irradiation, cells were re-cultured in a fresh media for $48 \mathrm{~h}$. Tumor cells were then incubated with recombinant TRAIL protein or agonistic antiFAS antibody for $3 \mathrm{~h}$ to induce apoptosis in the tumor cells. The percentage of apoptotic cells was determined by quantification of activated caspase- 3 using a flow cytometer. Irradiation significantly sensitized A2780-AD cells to killing by both TRAIL and anti-FAS treatments (Figure 3). Although, 2 Gy or 5 Gy sub-lethal ionizing radiation caused some background killing of tumor cells, the percentage of active caspase- 3 was significantly increased following TRAIL or anti-FAS treatment. These data suggest that the radiation can be used as an impactful tool on sensitization of resistant ovarian cancer cells to TRAIL and FAS mediated apoptosis.

\section{DISCUSSION}

Tumor cells frequently down-regulate genes that are essential for effective anti-tumor immunity to escape from immune responses (16). Following antigen introduction and proper stimulation, CTLS commonly use lytic granules and death receptors to kill tumor cells (17). Interaction between these death receptors with their ligands on anti-tumor immune cells is crucial to induce apoptotic signals in many types of tumor cells (18). Therefore, modulation of these molecules is a promising approach for improving the activity of tumor-specific T cells against resistant cancer cells and enhancing the efficacy of cancer immunotherapies (19). DR4 and DR5 interact with TRAIL, and FAS interacts with FASL to induce immune mediated apoptotic signals (20); hence it is possible that enhancing expression of death receptors may have therapeutic benefit for ovarian cancer.

In this study, we focused on immune-driven apoptosis by investigating the effect of sub-lethal ionizing radiation on the expression of death receptors. Our data significantly contribute to cancer immunotherapy studies by controlling the expression of death receptors for enhancing sensitivity of tumor 
cells to immune-mediated cytolysis. This study demonstrates that expressions of DR4 and FAS are significantly increased by sub-lethal ionizing radiation, which enhanced FASL or TRAIL mediated apoptosis. Primarily, the effect of the cisplatin on tumor cell death was investigated in parental chemosentitive and their derivative chemoresistant ovarian cancer cell lines. The majority of chemosensitive cells were killed following 100 $\mu \mathrm{M}$ cisplatin treatment while greater than $80 \%$ of chemoresistant cells were still remained viable at the same cisplatin concentration (Figure 1). The data clearly shows that most A2780-AD cells remain viable despite a high dose of cisplatin treatment, which confirms the resistance of A2780-AD cells to the chemotherapeutic drug cisplatin.

It has been reported that expression of multiple death receptors are modulated by ionizing radiation in colorectal cancer cells $(5,7)$, but the induction of radiation in chemoresistant ovarian cancer cells was unknown, and the role of sub-lethal radiation in expression of death receptors has not been investigated in resistant ovarian cancer cells. Our results demonstrate that 2 Gy or 5 Gy irradiation significantly reversed the expression of FAS and DR4 in the resistant tumor cells (Figure 2).

Enhancing tumor cells recognition by Natural killer cells or CTLs could increase the killing rate of tumor cells (21). Apoptosis is facilitated by a caspase cascade and activation of caspase- 3 is a hallmark of apoptosis (22). Thus, we measured the percentage of active caspase- 3 to determine the frequency of apoptotic cells following recombinant TRAIL protein or anti-FAS treatments. The goal was to test if the increase in the expression of death receptors by radiation would actually enhance the sensitivity of tumor cells to killing through TRAIL or FASL receptors in chemoresistant ovarian cancer cells. The data indicate that irradiation significantly sensitized A2780-AD cells to killing by anti-FAS or TRAIL (Figure 3). These data further suggest that sub-lethal ionizing radiation sensitizes ovarian tumor cells to apoptosis, possibly through up-regulation of death receptors on the ovarian tumor cells, which sensitizes these cells to FAS or TRAIL mediated killing (Figure 4). Thus, upregulated-expression of

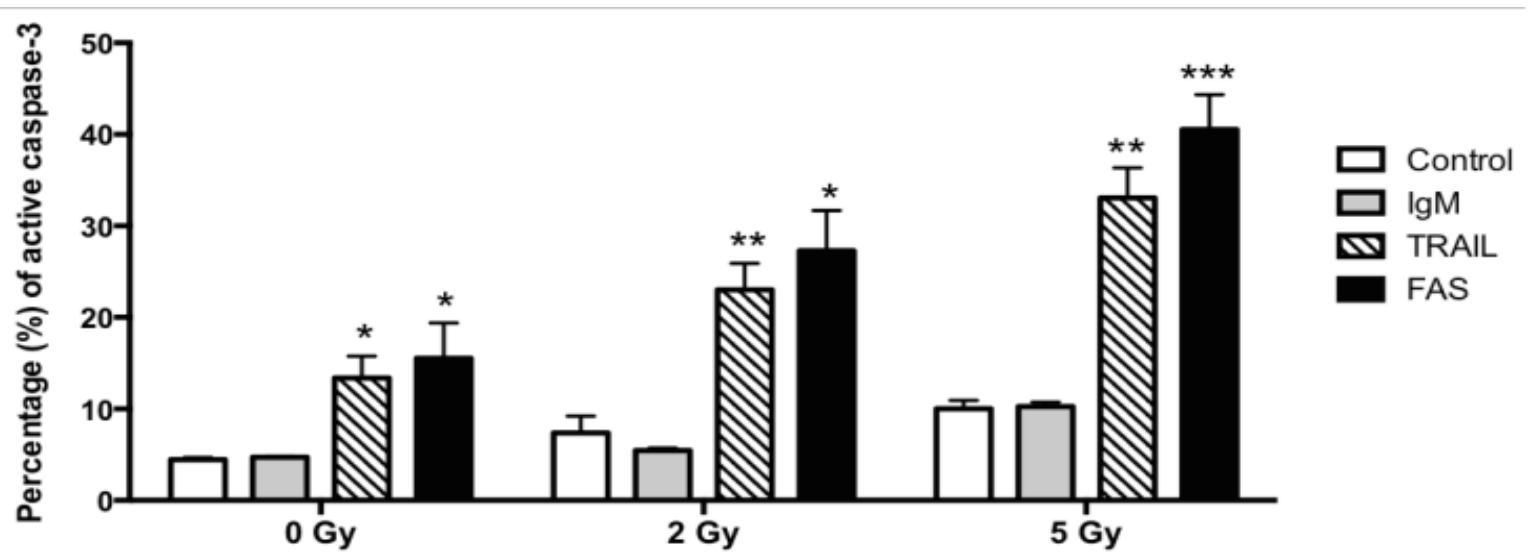

Figure 3. Sensitivity of chemoresistant cells to killing through FAS and TRAIL receptors following sub-lethal irradiation.

Tumor cells were mock-irradiated (0 Gy), irradiated with 2 or $5 \mathrm{~Gy}$ and cultured for $48 \mathrm{~h}$. The tumor cells were counted and then incubated for $3 \mathrm{~h}$ with recombinant TRAIL protein or agonistic anti-FAS antibody. Control cells were incubated with IgM isotype control antibody. The cells were subsequently fixed and permeabilized before being stained for intracellular active caspase- 3 with a PE-labeled monoclonal antibody. The level of activated caspase-3 was evaluated by flow cytometry. Graph shows average of three independent experiments. 


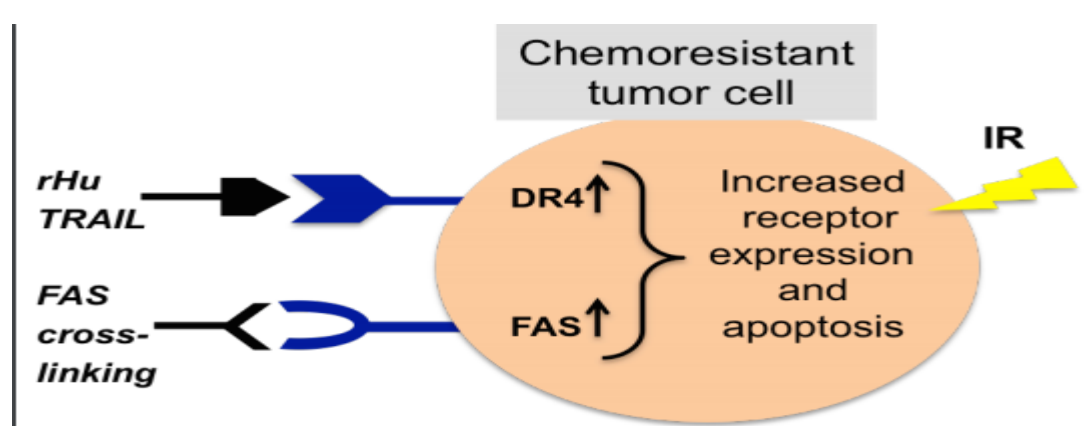

Figure 4. Immunogenic modulation of chemoresistant ovarian tumor cells by sub-lethal ionizing radiation (IR)

death receptors may improve the ability of CTLS activity and sensitivity to tumor cells. The data further suggest that radiation can be used for the treatment of advanced ovarian cancer by enhancing the induction of anti-tumor immune responses. Therefore, combination of radiation and immunotherapy could be a useful tool to enhance tumor sensitivity and $\mathrm{T}$ cell reactivity.
In the last two decades, research in the field of immunotherapy are trying to come up with new approaches and strategies for the treatment of malignant cancers and improving the prognosis of cancer $(23,24)$. Hence, our results further contribute to these studies to understand how sub-lethal radiation may be used to improve immunotherapy approaches for the treatment of advanced ovarian cancer.

\section{ACKNOWLEDGMENTS}

The author would like to thank to Dr. Susanna F. Greer for providing partial reagents.

\section{REFERENCES}

1. Smolle E, Taucher V, Haybaeck J. Malignant ascites in ovarian cancer and the role of targeted therapeutics. Anticancer research. 2014;34:155361.

2. McEvoy LM, O'Toole SA, Spillane CD, Martin CM, Gallagher MF, Stordal B, et al. Identifying novel hypoxia-associated markers of chemoresistance in ovarian cancer. BMC cancer. 2015;15:547.

3. Muallem MZ, Braicu I, Nassir M, Richter R, Sehouli $\mathrm{J}$, Arsenic R. ERCC1 expression as a predictor of resistance to platinum-based chemotherapy in primary ovarian cancer. Anticancer research. 2014;34:393-9.

4. Davis A, Tinker AV, Friedlander M. "Platinum resistant" ovarian cancer: what is it, who to treat and how to measure benefit? Gynecologic oncology. 2014;133:624-31.
5. Cacan E, Greer SF, Garnett-Benson C. Radiationinduced modulation of immunogenic genes in tumor cells is regulated by both histone deacetylases and DNA methyltransferases. International journal of oncology. 2015;47:2264-75.

6. Thorburn A. Death receptor-induced cell killing. Cellular signalling. 2004;16:139-44.

7. Cacan E, Spring AM, Kumari A, Greer SF, GarnettBenson C. Combination Treatment with Sublethal lonizing Radiation and the Proteasome Inhibitor, Bortezomib, Enhances Death-Receptor Mediated Apoptosis and Anti-Tumor Immune Attack. International journal of molecular sciences. 2015;16:30405-21.

8. Wang S, El-Deiry WS. TRAIL and apoptosis induction by TNF-family death receptors. Oncogene. 2003;22:8628-33. 
9. Kykalos S, Mathaiou S, Karayiannakis AJ, Patsouras D, Lambropoulou M, Simopoulos C. Tissue expression of the proteins fas and fas ligand in colorectal cancer and liver metastases. Journal of gastrointestinal cancer. 2012;43:224-8.

10. Yigit R, Massuger LF, Figdor CG, Torensma R. Ovarian cancer creates a suppressive microenvironment to escape immune elimination. Gynecologic oncology. 2010;117:366-72.

11. Zhu Q, Liu JY, Xu HW, Yang CM, Zhang AZ, Cui Y, et al. Mechanism of counterattack of colorectal cancer cell by Fas/Fas ligand system. World journal of gastroenterology : WJG. 2005;11:6125-9.

12. Cacan E. Histone Deacetylase-1-mediated Suppression of FAS in Chemoresistant Ovarian Cancer Cells. Anticancer research. 2016;36:281926.

13. Yang $F$, Long $\mathrm{W}$, Xuechuan $\mathrm{H}$, Xueqin L, Hongyun $\mathrm{M}$, Yonghui D. Upregulation of Fas in epithelial ovarian cancer reverses the development of resistance to cisplatin. BMB reports. 2015;48:30-5.

14. Schneiderman D, Kim JM, Senterman M, Tsang BK. Sustained suppression of Fas ligand expression in cisplatin-resistant human ovarian surface epithelial cancer cells. Apoptosis : an international journal on programmed cell death. 1999;4:271-81.

15. Di X, Zhang G, Zhang Y, Takeda K, Rivera Rosado LA, Zhang B. Accumulation of autophagosomes in breast cancer cells induces TRAIL resistance through downregulation of surface expression of death receptors 4 and 5. Oncotarget. 2013;4:134964.

16. Kim R, Emi M, Tanabe K. Cancer immunoediting from immune surveillance to immune escape. Immunology. 2007;121:1-14.
17. Guicciardi ME, Gores GJ. Life and death by death receptors. FASEB journal : official publication of the Federation of American Societies for Experimental Biology. 2009;23:1625-37.

18. Koornstra JJ, Kleibeuker JH, van Geelen CM, Rijcken FE, Hollema $\mathrm{H}$, de Vries EG, et al. Expression of TRAIL (TNF-related apoptosisinducing ligand) and its receptors in normal colonic mucosa, adenomas, and carcinomas. The Journal of pathology. 2003;200:327-35.

19. Driscoll PC. Structural studies of death receptors. Methods in enzymology. 2014;545:201-42.

20. Ozoren N, El-Deiry WS. Cell surface Death Receptor signaling in normal and cancer cells. Seminars in cancer biology. 2003;13:135-47.

21. Djeu JY, Jiang K, Wei S. A view to a kill: signals triggering cytotoxicity. Clinical cancer research : an official journal of the American Association for Cancer Research. 2002;8:636-40.

22. Fox R, Aubert M. Flow cytometric detection of activated caspase-3. Methods in molecular biology. 2008;414:47-56.

23. Coukos G, Tanyi J, Kandalaft LE. Opportunities in immunotherapy of ovarian cancer. Annals of oncology : official journal of the European Society for Medical Oncology / ESMO. 2016;27 Suppl 1:i11-i5.

24. Preston CC, Maurer MJ, Oberg AL, Visscher DW, Kalli KR, Hartmann LC, et al. The ratios of CD8+ $T$ cells to CD4+CD25+ FOXP3+ and FOXP3- T cells correlate with poor clinical outcome in human serous ovarian cancer. PloS one. 2013;8:e80063. 